Rival Queens 



\section{Rival Queens}

Actresses, Performance,

and the Eighteenth-Century

British Theater

Felicity Nussbaum

\section{$\overline{\text { PENN }}$}

UNIVERSITY OF PENNSYLVANIA PRESS

PHILADELPHIA • OXFORD 
Copyright (C) 20Io University of Pennsylvania Press

All rights reserved. Except for brief quotations used for purposes of review or scholarly citation, none of this book may be reproduced in any form by any means without written permission from the publisher.

Published by

University of Pennsylvania Press

Philadelphia, Pennsylvania I9IO4-4II2

Printed in the United States of America on acid-free paper

IO $\quad 9 \begin{array}{llllllll}8 & 7 & 6 & 5 & 4 & 3 & 2 & \text { I }\end{array}$

Library of Congress Cataloging-in-Publication Data

Nussbaum, Felicity.

Rival queens : actresses, performance, and the eighteenth-century British theater / Felicity Nussbaum.

p. $\mathrm{cm}$.

ISBN 978-0-8122-4233-I (alk. paper)

Includes bibliographical references and index.

I. Women in the theater-Great Britain-History-I8th century. 2. Theater and society-Great Britain-History-I8th century. 3. Actresses-Great Britain-Biography.

$\mathrm{PN} 2582$. W65 $\mathrm{N} 87 \quad 2010$

792.02 '8082094109033-dc22

2009029041 
For my students 
